\title{
VOLATILE COMPONENT COMPOSITION OF BALLOTA NIGRA SUBSP. ANATOLICA AT DIFFERENT VEGETATION PERIODS IN ÇAMLICA PROVINCE OF KÜTAHYA CITY, TURKEY
}

\author{
SARIKAYA, A. G. \\ Suleyman Demirel University, Atabey Vocational School, Isparta, Turkey \\ e-mail: aysegulsarikaya@sdu.edu.tr; phone:+90-246-271-30-36/120 \\ (Received $19^{\text {th }}$ Aug 2017; accepted $27^{\text {th }}$ Oct 2017)
}

\begin{abstract}
The volatile component composition of leaves and flowers for Ballota nigra subsp. anatolica P.H. Davis that were collected between 2015 and 2016 from Çamlıca provice of Kütahya city during three different vegetation periods as pre-bloom, bloom and post flowering were determined by gas chromatography mass spectroscopy (GC-MS) after solid phase micro extraction (SPME). 59 different volatile oil components were determined of Ballota nigra subsp. anatolica. As main components, Hexenal (17.60\%), germacrene D $(6.70 \%)$ and $\beta$-caryophyllene $(8.80 \%)$ were found during pre-blooming period, also Hexenal $(21.16 \%)$, germacrene D $(7.77 \%)$ and $\beta$-caryophyllene $(10.03 \%)$ in blooming period and Hexenal (15.88\%), germacrene D (7.60\%) and $\beta$-caryophyllene $(9.48 \%)$ in post-flowering period.
\end{abstract}

Keywords: SPME, black horehound, volatile component, Lamiaceae

\section{Introduction}

The research on the essential oil content of medicinal plants is quite important both in scientific and economic aspects. The increase in microorganism resistance against all known antibiotics has made it necessary to investigate plant sources and their effects on cells. There are also essences, most of which constitute essential oils in medicines as well as some substances such as cellulose, pectin, sugar and it is known that these substances have an important pharmacological effect (Kilic, 2005)

Lamiaceae family, one of the greatest families that can be grown almost anywhere without discrimination of habitat type and height, is the most spread especially in the Mediterranean Basin (Watson and Dallwitz, 1978). This family has 200 genus and approximately 3200 species and family members represented with 45 genus and more than 546 species in Turkey are important in pharmacology and perfumery industry because they contain essential and aromatic oil (Davis, 1982, Baytop, 1991). Lamiaceae has a rate of endemism of $44.2 \%$ in Turkey (Baser, 1993).

The genus Ballota L., which is a member of the Lamiaceae family that constitutes the material of this study, has about 35 taxa around the world (Patzak, 1958). It is represented with 12 species and 8 subspecies in Turkey (Guner, 2012). Ballota L. is a well-known genus in Europe due to its spasmolytic and sedative effects (Garnier et al., 1961). It is used in folk medicine for cough, asthma, headache, nausea, hemorrhoids, wound and burn treatment (Baytop, 1984).

The Black horehound (Ballota nigra) bearing only simple hairs. Stems erect, 50-100 $\mathrm{cm}$, simple or branched above. Cauline leaves ovate-orbicular to ovate, 25-70 x 20-50 $\mathrm{mm}$, acute, crenate dentate, truncate or rounded at base, distinctly petiolate. Inflorescence long, lax below. Floral leaves 1-2 x dense verticillasters. Bracteoles subulate, usually shorter than calyx tube. Calyx 7-10 mm, tubular obconical, dilated above into usually 5 , very short to attenuate teeth that are porrect to patent or recurved, 
mucronate or aristate. Corolla purple or pink, 9-14 mm; upper lip concave, emarginate or erose (Davis, 1982; Anonymous, 2016).

In this study, volatile components of leaf and flower of Ballota nigra subsp. anatolica P.H. Davis, that belong to three different vegetation periods including prebloom, bloom and post-flowering were determined by SPME (solid-based microextraction method).

\section{Materials and Methods}

The materials of this study which was conducted in 2015 and 2016 are leaves and flower samples of Ballota nigra subsp. anatolica P.H. Davis that were collected in 3 different periods as pre-flowering term, flowering term and post-flowering from Çamlica province $\left(39^{\circ} 43^{\prime} \mathrm{N}, 29^{\circ} 91^{\prime} \mathrm{E}\right)$ of Kütahya city which is situated in the inner part of western Turkey.

The leaves and flower samples that were collected were put into paper packages and transferred to the laboratory in the same day without kept waited and exposed to sunlight. After the plant materials collected were dried at room temperature $\left(25^{\circ} \mathrm{C}\right)$, flower and leaf samples were subjected to solid phase microextraction (SPME). $2 \mathrm{~g}$ of samples were placed into a $10 \mathrm{~mL}$ vial. After incubation for $30 \mathrm{~min}$ at $60^{\circ} \mathrm{C}$, SPME fibre was pushed through the headspace of a sample vial to adsorbed the volatiles, and then inserted directly into the injection port of the GC-MS (Shimadzu 2010 Plus GCMS with the capillary column, Restek Rxi ${ }^{\circledR}-5$ Sil MS $30 \mathrm{~m} \times 0.25 \mathrm{~mm}, 0.25 \mu \mathrm{m}$ ) at a temperature of $250^{\circ} \mathrm{C}$ for desorption $(5 \mathrm{~min})$ of the adsorbed volatile compounds for analysis. Identification of constituents was carried out with the help of retention times of standard substances by composition of mass spectra with the data given in the Wiley, NIST Tutor, FFNSC libraries.

\section{Results}

59 different volatile components were specified by gas chromatography mass spectroscopy (GC-MS) after solid phase micro extraction (SPME) for Ballota nigra subsp. anatolica. The results are given in Table 1. Hexenal, germacrene D and $\beta$ caryophyllene were specified as the main components of Ballota nigra subsp. anatolica. Hexenal $(17.60 \%)$, germacrene D $(6.70 \%)$, and $\beta$-caryophyllene $(8.80 \%)$ in the prebloom period; Hexenal $(21.16 \%)$, germacrene D $(7.77 \%)$ and $\beta$-caryophyllene $(10.03 \%)$ in the bloom period, Hexenal (15.88\%), germacrene D (7.60\%), $\beta$-caryophyllene $(9.48 \%)$ in post flowering period were identified (Table 1). It was observed that there was an increase in the proportion of volatile components during the bloom period.

Table 1. Volatile components of Ballota nigra subsp. anatolica P.H. Davis according to different vegetation periods

\begin{tabular}{|c|c|l|c|c|c|}
\hline & $\begin{array}{c}\text { Retention } \\
\text { Time }\end{array}$ & \multicolumn{1}{|c|}{ Components } & $\begin{array}{c}\text { Pre-bloom } \\
(\mathbf{\%})\end{array}$ & $\begin{array}{c}\text { Bloom } \\
(\mathbf{\%})\end{array}$ & $\begin{array}{c}\text { Post-flowering } \\
(\mathbf{\%})\end{array}$ \\
\hline $\mathbf{1}$ & 1.401 & Isobutanal & 0.17 & 0.70 & - \\
\hline $\mathbf{2}$ & 1.438 & 2-Methylpropenal & - & 0.87 & - \\
\hline $\mathbf{3}$ & 1.549 & 2-Ethylbutanal & 1.52 & 1.14 & 1.20 \\
\hline $\mathbf{4}$ & 1.581 & 2-Methylfuran & 1.10 & 0.96 & 1.30 \\
\hline $\mathbf{5}$ & 1.635 & 3-Methylfuran & 0.93 & 0.48 & 0.70 \\
\hline
\end{tabular}




\begin{tabular}{|c|c|c|c|c|c|}
\hline & $\begin{array}{c}\text { Retention } \\
\text { Time }\end{array}$ & Components & $\begin{array}{c}\text { Pre-bloom } \\
(\%)\end{array}$ & $\begin{array}{c}\text { Bloom } \\
(\%)\end{array}$ & $\begin{array}{c}\text { Post-flowering } \\
(\%)\end{array}$ \\
\hline 6 & 1.910 & 2-Butenal & 1.17 & 1.39 & 0.64 \\
\hline 7 & 1.949 & 3-Methylbutanal & 1.41 & 1.24 & 0.55 \\
\hline 8 & 2.031 & 2-Methylbutanal & 1.33 & 1.38 & 0.25 \\
\hline 9 & 2.246 & 1-Ethylcyclopropanol & 1.70 & 1.30 & 0.75 \\
\hline 10 & 2.372 & \begin{tabular}{|l|} 
Pentanal \\
\end{tabular} & 6.16 & 6.93 & 6.32 \\
\hline 11 & 2.970 & (E)-3-Penten-2-one & 1.30 & 0.85 & 1.11 \\
\hline 12 & 3.025 & 3-Methylenepentane & 0.27 & 0.33 & 0.20 \\
\hline 13 & 3.260 & (E)-2-Pentenal & 1.57 & 0.90 & 0.59 \\
\hline 14 & 3.544 & 2-methyl-1-Penten-3-one & 0.55 & 0.40 & - \\
\hline 15 & 3.584 & Pentanol & - & 0.38 & 0.32 \\
\hline 16 & 3.642 & 2-Penten-1-ol & 0.44 & 0.26 & 0.25 \\
\hline 17 & 3.870 & 3-Methyl-2-butenal & 0.45 & 0.25 & 0.55 \\
\hline 18 & 4.037 & 2-Acetylfuran & 0.55 & 0.22 & 0.25 \\
\hline 19 & 4.225 & Hexanal & 17.60 & 21.16 & 15.88 \\
\hline 20 & 5.692 & (E)-2-Hexenal & 3.06 & 3.00 & 3.20 \\
\hline 21 & 5.855 & cis-3-Hexene-1-ol & 5.65 & 6.83 & 5.52 \\
\hline 22 & 6.184 & trans-2-Hexen-1-ol & 0.70 & 0.42 & 0.44 \\
\hline 23 & 6.302 & Hexanol & 0.67 & 0.56 & 2.20 \\
\hline 24 & 6.572 & 2,6-dimethyl-Pyridine & 0.50 & 0.51 & - \\
\hline 25 & 6.808 & 2-Heptanone & 0.50 & 0.50 & 0.71 \\
\hline 26 & 7.137 & (Z)-4-Heptenal & - & 0.20 & 0.40 \\
\hline 27 & 7.218 & Heptanal & 0.39 & 0.53 & 0.20 \\
\hline 28 & 7.548 & 2,4-Hexadienal & 0.54 & 0.68 & 0.50 \\
\hline 29 & 8.007 & $\alpha$-thujene & 1.48 & 0.14 & 1.66 \\
\hline 30 & 8.238 & $\alpha$-pinene & 1.20 & 0.31 & 1.85 \\
\hline 31 & 8.321 & 2,7- Dimethyloxepine & 0.17 & 0.18 & - \\
\hline 32 & 9.088 & 6-methyl-2-Heptanone & 0.30 & 0.20 & 0.30 \\
\hline 33 & 9.193 & (Z)-2-Heptenal & 1.50 & 1.30 & 1.25 \\
\hline 34 & 9.353 & Benzaldehyde & 1.74 & 1.52 & 2.12 \\
\hline 35 & 9.974 & Cyclopentane, 1,2,4-trimethyl-, $(1 \alpha)$ & 0.71 & 0.64 & 0.33 \\
\hline 36 & 10.281 & 1-octen-3-ol & 0.80 & 0.20 & 1.34 \\
\hline 37 & 10.446 & 2-pentyl-Furan & 2.40 & 2.34 & 2.23 \\
\hline 38 & 10.732 & (E,E)-2,4-Heptadienal, & 1.87 & 1.46 & 2.82 \\
\hline 39 & 10.881 & <ethyl->Hexanol & 0.82 & 0.28 & 0.63 \\
\hline 40 & 10.960 & Octanal & 0.90 & 0.73 & 0.51 \\
\hline 41 & 11.297 & (E,E)-2,4-Heptadienal & 1.27 & 1.44 & 1.94 \\
\hline 42 & 11.765 & p-Cymene & 1.53 & 1.67 & 1.49 \\
\hline 43 & 11.913 & Limonene & 4.67 & 5.24 & 5.70 \\
\hline 44 & 12.312 & 3-Octen-2-one & 1.96 & 1.90 & 2.51 \\
\hline 45 & 12.496 & Bicyclo[6.1.0]nona-5,8-dien-4-one & 1.14 & 1.04 & 1.13 \\
\hline 46 & 12.794 & 2-ethyl-6-meth-1,5-heptadiene & 0.30 & 0.25 & 0.23 \\
\hline 47 & 13.076 & 2 Octenal & 0.34 & 0.39 & 0.41 \\
\hline 48 & 13.545 & 3,5-octadien-2-one & 1.13 & 0.85 & 1.49 \\
\hline 49 & 14.393 & 1-Undecene & 2.45 & 2.73 & 2.65 \\
\hline 50 & 14.886 & Nonanal & 1.39 & 1.07 & 1.59 \\
\hline 51 & 18.263 & Methyl salicylate & 0.82 & 0.60 & 0.85 \\
\hline 52 & 18.787 & Decanal & 0.30 & 0.19 & 0.30 \\
\hline 53 & 21.967 & 3-hexadecene & 0.40 & 0.25 & 0.60 \\
\hline 54 & 24.845 & Copaene & 1.23 & 0.21 & 1.57 \\
\hline 55 & 25.118 & $\beta$-bourbonene & 0.41 & 0.37 & 0.54 \\
\hline 56 & 26.328 & Germacrene D & 6.70 & 7.77 & 7.60 \\
\hline 57 & 26.076 & $\beta$-caryophyllene & 8.80 & 10.03 & 9.48 \\
\hline
\end{tabular}




\begin{tabular}{|l|c|l|c|c|c|}
\hline & $\begin{array}{c}\text { Retention } \\
\text { Time }\end{array}$ & \multicolumn{1}{|c|}{ Components } & $\begin{array}{c}\text { Pre-bloom } \\
(\boldsymbol{\%})\end{array}$ & $\begin{array}{c}\text { Bloom } \\
(\boldsymbol{\%})\end{array}$ & $\begin{array}{c}\text { Post-flowering } \\
(\boldsymbol{\%})\end{array}$ \\
\hline $\mathbf{5 8}$ & 28.390 & Cyclopropanecarboxylic acid 2,2-dimeth & 0.82 & 0.17 & 0.65 \\
\hline $\mathbf{5 9}$ & 31.585 & Caryophyllene oxide & 0.22 & 0.16 & 0.20 \\
\hline
\end{tabular}

\section{Discussion and Conclusions}

Bader et al. (2003) studied the volatile oil components of Ballota nigra ssp. foetida, B. undulata and B. saxatilis. $\beta$-caryophyllene (25.1\%) and germacrene D (24.2\%) were identified as the main components of Ballota nigra ssp. foetida. Morteza-Semnani et al. (2007) determined 42 components, specifying caryophyllene oxide (7.9\%), epi- $\alpha$ muurolol $(6.6 \%), \delta$-cadinene $(6.5 \%)$, and $\alpha$-cadinol $(6.3 \%)$ as the main components. The main components differ according to our study. Kazemizadeh et al. (2009) found the germacrene D (18.1\%), nerolidol epoxyacetate (15.4\%), sclareol oxide $(12.1 \%)$, linalyl acetate $(11.5 \%)$, and $\beta$-caryophyllene $(10.5 \%)$ as the main components in $B$. nigra subsp. anatolica. Vukovic et al. (2009) determined 115 components in Ballota nigra in Serbia. They reported that $\beta$-caryophyllene, germacrene $\mathrm{D}$, and $\alpha$-humulene in the leaves and stalks, p-vinylguiacol (9.24\%), borneol (7.51\%), myrtenol $(7.13 \%)$, trans-pinocarveol $(5.22 \%)$, pinocarvone $(4.37 \%)$, 2-methyl-3-phenylpropanal $(4.32 \%)$, and p-cymen-8-ol $(4.30 \%)$ in the roots as the main components.

Fraternale et al. (2009) identified 37 components in Ballota nigra. They found $\beta$ caryophyllene $(20.0 \%)$, germacrene D $(18.0 \%)$, and caryophyllene oxide $(15.0 \%)$ as the main components. Fraternale and Ricci (2014) have specified $\beta$-caryophyllene $(22.6 \%$ and $21.8 \%$ ), caryophyllene oxide (18.0\% and 20.5\%) and germacrene D (16.5 and $13.1 \%$ ) as the main components in Ballota nigra L. ssp. foetida. In our study, germacrene $\mathrm{D}(7.77 \%)$ and $\beta$-Caryophyllene were determined as the main components, sharing similarities to other works. Unlike other studies, hexenal component were identified.

Jamzad et al. (2013) reported 12 different components including $\beta$-pinene (39.0\%) and $\alpha$-pinene $(34.5 \%)$. However, 59 different components were found, specifying Hexenal $(21.1 \%)$, germacrene D $(7.77 \%)$ and $\beta$-caryophyllene $(10.03 \%)$ as the main components. The main components in our work differ from those of Jamzad et al. (2013).

As conclusion; Ballota taxa are consumed in South Anatolian regions against cough, asthma, headache, nausea and hemorrhoids, and they are used externally in wound and burn treatment. Studies should be increased for people to consume and use consciously. It is considered that local people will be informed, random collection of plants and economic losses to be incurred due to false information will be prevented, and collection of plants will be performed more consciously. Further studies related to volatile components and possibilities of their usage within the scope of antibacterial, antimicrobial and deterrent etc. should be investigated.

\section{REFERENCES}

[1] Anonymous (2016): www.turkiyebitkileri.com, Access date: 14.10.2016.

[2] Bader, A., Caponi, C., Cioni, P.L., Flamini, G., Morelli, I. (2003): Composition of the essential oil of Ballota undulata, B. nigra ssp. foetida and B. saxatilis. -Flavour And Fragrance Journal 18: 502-504.

[3] Baser, K.H.C. (1993): Essential oils of Anatolian Labiatae: A profile. -Acta Horticulture. 
333: $217-238$.

[4] Baytop, T. (1984): Türkiye'de Bitkiler İle Tedavi. -Istanbul University Press, Istanbul.

[5] Baytop, T. (1991): Farmasotik Botanik Ders Kitabı. - Istanbul University Press, Istanbul.

[6] Davis, P. H. (1982): Flora of Turkey and The East Aegaen Islands, 7. -Edinburg University Press, Edinburg.

[7] Fraternale, D., Bucchini, A., Giamperi, L., Ricci, D. (2009): Essential oil composition and antimicrobial activity of Ballota nigra L. ssp foetida. -Natural Product Communications 4: $585-588$.

[8] Fraternale, D., Ricci, D. (2014): Essential oil composition and antifungal activity of aerial parts of Ballota nigra ssp. foetida collected at flowering and fruiting times. -Natural Product Communications 9: 1015-1018.

[9] Garnier, G., Bezanger-Beauquesne, L., Debraux, G. (1961): Ressources Medicinales de la Flore Fransais. -Uigot Frerer Ed, Paris.

[10] Guner, A. (2012): Türkiye Bitkileri Listesi, Damarlı Bitkiler. -Nezahat Gökyiğit Botanik Bahçesi Yayınları, Istanbul.

[11] Jamzad, M., Rustaiyan, A., Jamzad, Z., Masoudi, S. (2013): Essential Oil Composition of Salvia indica L., Thymus caucasicus Wind. Ex Ronniger subsp. Grossheimii (Ronniger) Jalas. and Ballota nigra L. Three Labiatae Species from Iran. -Journal of Essential Oil Bearing Plants 14: 76-83.

[12] Kazemizadeh, Z., Amini, T., Nazari, F., Habibi, Z. (2009): Volatile Constituents of Ballota nigra subsp. anatolica From Iran. -Chemistry of Natural Compounds 45: 737738.

[13] Kilic, A. (2005): Bitkisel Kaynaklı Bazı Uçucu Yağ ve Monoterpenlerin Olası Genotoksik Etkilerinin Araştırılması. -Anadolu Üniversitesi Biyoloji Anabilim Dalı, Yüksek Lisans Tezi, Eskisehir.

[14] Morteza-Semnani, K., Saeedi, M., Akbarzadeh, M. (2007): The Essential Oil Composition of Ballota nigra. -Chemistry of Natural Compounds 43: 722-723.

[15] Patzak, V. A. (1958): Revision der Gattung Ballota section Acanthoprasium und section Beringeri. -Annalen des Naturhistorischen Museums in Wien. 62: 57-86.

[16] Vukovic, N., Sukdolak, S., Solujic, S., Niciforovic, N. (2009): Antimicrobial Activity of the Essential Oil Obtained from Roots and Chemical Composition of the Volatile Constituents from the Roots, Stems, and Leaves of Ballota nigra from Serbia. -Journal of Medicinal Food 12: 435-441.

[17] Watson L., Dallwitz, M. T. (1978): The Families of Flowering Plants. - Oxford University Press., London. 